\title{
NILAI GIZI KONSENTRAT PROTEIN IKAN LELE DUMBO (Clarias gariepenus) UKURAN JUMBO
}

\section{STUDY OF CHARACTERISTICS KPI FISH LELE DUMBO (Clarias gariepenus) JUMBO SIZE}

\author{
Asriani $^{\# 1,2}$, Joko Santoso ${ }^{3}$, dan Sri Listyarini ${ }^{1}$ \\ ${ }^{1}$ Universitas Terbuka
}

Jalan Cabe Raya, Pondok Cabe, Pamulang, Pd. Cabe Udik, Pamulang, Kota Tangerang Selatan, Banten 15418

${ }^{2}$ Sekolah Tinggi Perikanan

Jl. AUP Pasar Minggu Jakarta Selatan 12520

${ }^{3}$ Institut Pertanian Bogor

Jl. Raya Dramaga Kampus IPB Dramaga Bogor 16680

E-mail: asriani_hs@yahoo.co.id

(Diterima: 15 November 2018; Diterima setelah perbaikan: 14 Januari 2019; Disetujui: 14 Januari 2019)

\begin{abstract}
ABSTRAK
Ikan lele dumbo pada umumnya dikonsumsi pada size 6-8 ekor $/ \mathrm{kg}$, ukuran 2 -1 ekor / kg tergolong ukuran jumbo kurang laku, pangsa pasarnya sangat terbatas. Konsentrat protein ikan (KPI) merupakan bahan pangan untuk konsumsi manusia, dengan jumlah protein yang dihasilkan lebih banyak dari kondisi awalnya. Faktor-faktor yang mepengaruhi mutu KPI antara lain jenis ikan, jenis pelarut, cara ekstraksi dan lama ekstraksi. Penelitian ini dilakukan untuk mengetahui jenis pelarut terbaik dan ulangan ekstraksi, pembuatan KPI berbahan baku ikan lele dumbo ukuran jumbo. Ikan lele dumbo di ekstrak menggunakan pelarut isopropil alkohol dan etanol, ekstraksi dilakukan 1 kali, 2 kali. 3 kali dan 4 kali. Hasil penelitian pelarut terbaik menggunakan pelarut isopropil alkohol 90\%, pengulangan ekstraksi 4 kali, menghasilkan kadar protein $78,71 \%$, kadar lemak $0,69 \%$, derajat putih 84 , nilai organoleptik 4,29 bau ikan sangat lemah, memiliki 8 asam amino esensial, 5 asam amino non esensial dan 2 asam amino semi esensial.KPI ikan lele dumbo ukuran jumbo berupa produk dalam bentuk tepung berwarna putih yang mudah diplikasikan sebagai bahan fortifikasi.
\end{abstract}

\section{KATA KUNCI: Ikan lele; KPI; ekstraksi}

\section{ABSTRACT}

Dumbo catfish generally consumed in size 6-8 fishes / $\mathrm{kg}$, size 1 - 2 fishes / $\mathrm{kg}$ is classified as a jumbo size which is less salable and the market share is very limited. Fish protein concentrate (KPI) is a product for human consumption, with the amount of protein more than the original condition. Factors that affected of the KPI quality is fish type, solvent type, extraction method and extraction time. This research was conducted to find out the best type of solvent and extraction repetition in making of KPI from dumbo catfish. Dumbo catfish was extracted using isopropyl alcohol and ethanol solvent, extraction was done by once, 2 times, 3 times and 4 times. The best result is using isopropyl alcohol $90 \%$ solvent, 4 times of the extraction repetition. That treatment was contained $78.71 \%$ of protein content, $0.69 \%$ of fat content, 84 of white degrees, 4,29 of organoleptic value in fish odor was very weak, had at least 8 essential amino acids, 5 non essential amino

\footnotetext{
\# Korespondensi: Universitas Terbuka

E-mail: asriani_hs@yahoo.co.id
} 
acids and 2 semi essential amino acids. KPI from jumbo size dumbo catfish is the product in the white flour form which is easily applied as a food fortification material.

\section{KEYWORDS: Dumbo catfish; KPI; Extraction}

\section{PENDAHULUAN}

Masalah kurang energi protein (KEP) masih merupakam masalah utama di bidang kesehatan yang belum seluruhnya terpecahkan di Indonesia, walaupun usaha perbaikan gizi keluarga oleh pemerintah maupun nonpemerintah sudah banyak dilakukan. Masalah makanan akan berpengaruh terhadap nilai gizi, karena masalah gizi timbul sebagai akibat kekurangan atau kelebihan kandungan zat gizi dalam makanan (Ariani 2010). Kurang energi protein (KEP) dapat terjadi akibat asupan makanan yang tidak mengandung energi dan protein serta karena adanya infeksi kronik atau berulang-ulang (Haslina et al. (2006). Tersedianya berbagai jenis makanan bergizi dapatdipenuhi antara lain melalui pengayaan makanan dengan bahan-bahan yang memenuhi persyaratan untuk meningkatkan asupan makanan pada anak-anak maupun orang dewasa.

Jenis ikan lele yang populer di masyarakat adalah lele dumbo (Clarias gariepinus). Hal ini dikarenakan ikan lele dumbo mempunyai beberapa kelebihan dibandingkan dengan ikan lele lokal. Kelebihan tersebut dintaranya, yaitu pertumbuhannya 5-6 kali lebihcepat dibanding lele lokal (Alamendah, 2009). Menurut Khairuman \& Khairul (2002) ikan lele dumbo memiliki kemampuan beradaptasi terhadap lingkungan yang tinggi, mempunyai rasa daging yang enak dan kandungan gizi yang tinggi.

Peningkatan produksi akan berakibat kerugian usaha budidaya apabila tidak disertai dengan inovasi teknologi hasil pengolahannya. Hal ini disebabkan karena konsumsi terbesar ikan lele masih dalam bentuk segar, belum banyak bentuk olahan. Disamping itu masih ada persepsi masyarakat terhadap ikan lele masih negatif, karena bentuk, warna kulitnya hitam dan berlendir sehingga terkesan menjijikan. Adakalanya pembudidaya tidak dapat menjual produksinya karena pasar kelebihan pasokan, sehingga ikan lele dibiarkan di kolam. Apabila tidak segera dipanen untuk dijual, maka ukuran ikan semakin besar dan melebihi ukuran konsumsi 8-10 ekor/kg. Hal ini menyebabkan harga lele menjadi jatuh, apalagi ukurannya lebih dari 500 g per ekor digolongkan sebagai lele dumbo ukuran jumbo pangsa pasarnya sangat terbatas.

Ikan lele dumbo ukuran jumbo jumlahnya mencapai $10 \%$ dalam tiap siklus produksinya dan ikan lele dumbo ukuran jumbo tidak laku dijual jika laku dengan harga murah sehingga dapat merugikan pembudidaya. Upaya mengatasi masalah ini, khususnya di sektor perikanan perlu dilakukan untuk memanfaatkan potensi dan produksi perikanan semaksimal mungkin agar bisa meningkatkan pendapatan masyarakat, terutama pembudidaya dan pelaku usaha perikanan. Salah satu peluang yang dapat dikembangkan adalah dengan memperluas atau mengembangkan pemasaran hasil perikanan melalui fortifikasi konsentrat protein ikan pada produk melarat.

Ikan lele dumbo memiliki protein yang tinggi 17,7$26,7 \%$ dan lemaknya berkisar 0,95 sampai dengan $11,5 \%$ (Nurilmala et al., 2009). Rosa et al. (2007) melaporkan bahwa ikan lele dapat dikelompokkan kedalam bahan pangan berprotein sedang dengan lemak rendah. Ikan lele juga mengandung karoten, vitamin $\mathrm{A}$, fosfor, kalsium, zat besi, vitamin B1, vitamin B6, vitamin B12 dan kaya asam amino. Rohimah et al. (2014) menyebutkan bahwa kandungan komponen gizi ikan lele mudah dicerna dan diserap oleh tubuh manusia baik anak-anak, dewasa maupun orang tua. Rosa et al. (2007) mengatakan lele memiliki manfaat untuk membantu pertumbuhan dan perkembangan pada anak, kandungan asam amino esensial sangat berguna untuk pertumbuhan tulang membantu penyerapan kalsium dan menjaga, keseimbangan nitrogen dalam tubuh dan memelihara masa tubuh anak agar tidak terlalu berlemak. Konsentrat protein ikan (KPI) merupakan bahan pangan untuk konsumsi manusia, dengan jumlah protein yang dihasilkan lebih banyak dari kondisi awalnya karena terkonsentrasi (Windsor, 2001). KPI memiliki kadar protein tinggi dengan daya cerna yang tinggi pula. KPI terbagi pada tiga tipe, yaitu tipe A (kadar protein minimal 67,5\% dan kadar lemak maksimal 0,75\%), tipe B (kadar protein minimal 67,5\% dan kadar lemak maksimal 3\%) dan tipe C (kadar protein minimal 67,5\% dan kadar lemak maksimal 10\%) (Buckle et al., 1987).

Pembuatan konsentrat protein ikan merupakan inovasi pengembangan bentuk protein yang mudah diaplikasikan ke dalam produk pangan berprotein rendah. Menurut Ibrahim (2009), konsentrat protein ikan merupakan produk yang dihasilkan dengan cara menghilangkan lemak dan air sehingga menghasilkan konsetrat protein yang tinggi. Kebanyakan produk ini diaplikasikan ke dalam makanan yang berkarbohidrat tinggi. Penelitian KPI telah banyak dilakukan antara lain Tirtajaya et al. (2008) pemanfaatan konsentrat protein ikan patin (Pangasius pangasius) pada pembuatan cookies coklat. Dewita et al. (2011) memanfaatkan konsentrat protein ikan 
patin (Pangasius pangasius) untuk pembuatan biskuit dan snack. Siahaan et al. (2015) melakukan penelitan penambahan konsentrat protein ikan gabus (Channa striatus) terhadap mutu kwetiau. Ikan lele afkir mempunyai rendemen yang tinggi namun belum banyak dimanfaatkan, sehingga sangat potensial untuk dikembangkan menjadi konsentrat protein ikan. Ikan lele sebagai salah satu bahan mengandung protein yang tinggi yang dapat dilakukan untuk fortifikasi dalam bentuk konsentrat protein ikan (KPI) ditujukan khusus untuk konsumsi manusia dan diproduksi dengan cara menghilangkan sebagian besar kandungan air dan lemak yang terdapat pada ikan sehingga KPI memiliki kandungan protein yang tinggi. Komposisi zat gizi ikan pada umumnya mengandung $15-2 \%$ protein, 0,1 - $22 \%$ lemak, 1 - $3 \%$ karbohidrat, 0,8 - $2 \%$ mineral dan $66-84 \%$ air (Suzuki, 1981). Perbedaan Protein ikan banyak mengandung asam amino esensial.

Kandungan asam amino dalam daging ikan tergantung dari jenis ikannya. Umumnya asam amino dalam daging ikan kaya akan lisin tetapi kekurangan tritofan (Suzuki, 1981 ) komposisi ini dipengaruhi oleh perbedaan spesies antar individu dalam spesies, atar bagian dalam suatu individu, jenis kelamin, musim, daerah penangkapan. Ikan lele dumbo banyak mengandung asam amino glutamat dan mengandung asam amino sistin yang paling sedikit. Selain asam amino penyusun protein, daging ikan juga mengandung asam amino bebas dan senyawa nitrogen non protein lain seperti trimetilamin (TMAO), urea, taurin, peptida, nukleotida (Muchtadi,1993). Konsentrat protein ikan adalah produk olahan ikan untuk konsumsi manusia yang dibuat dari ikan utuh atau bagian-bagiannya, dengan cara menghilangkan sebagian besar lemak dan kandungan airnya, sehingga diperoleh produk dengan kadar protein yang lebih tinggi dibandingkan dengan bahan baku asalnya (Muchtadi,2008). Suzuki (1981) menyatakan bahwa pembuatan konsentrat protein pada umumnya dilakukan dengan dua metoda. Metode pertama dimulai dengan pemisahan daging, penghancuran dan pencucian dengan air, pengurangan lemak dengan pelarut organik pada suhu tinggi $\left(75^{\circ} \mathrm{C}\right)$, pengeringan dan penepungan. Metode kedua dimulai dengan pemisahan daging, penghancuran dan pencucian dengan air dingin dan penambahan $\mathrm{NaCl} 0,5-1 \%$ pada $\mathrm{Ph}$ 7.4-7.8, pengurangan lemak dengan pelarut organik pada suhu rendah $\left(5^{\circ} \mathrm{C}\right)$, pengeringan dan penepungan. Koesoemawardani dan Nurainy (2008) menyatakan untuk mengekstrak konsentrat protein ikan dapat menggunakan pelarut organik contohnya iso-propanol, metanol, etanol atau 1,2 dikloroetana dengan variasi waktu dan suhu yang berbeda untuk menghilangkan lemak dan air sehingga diperoleh kadar protein yang tinggi. Penggunaan pelarut alkohol dapat menghasilkan KPI dengan mutu yang baik, walaupun ekstraksi dengan alkohol memiliki kelemahan yaitu masih terdapat aroma pelarut pada KPI yang dihasilkan. Proses untuk menghilangkan air dan lemak tersebut dapat dilakukan dengan pengepresan, pengeringan atau ekstraksi. Ada beberapa faktor yang harus diperhatikan untuk memperoleh KPI dengan mutu tinggi antara lain jenis ikan, cara ekstraksi, tahap proses, bahan baku dan waktu ekstraksi. Isopropil alkohol dan etanol adalah pelarut komersial yang sering digunakan dalam proses ekstraksi KPI memiliki kelemahan yaitu masih terdapat aroma pelarut pada KPI yang dihasilkan. Beberapa penelitian yang menggunakan etanol dan isopropil alkohol untuk mengestrak protein ikan antaranya Astawan, (1990 ) mengekstrak protein ikan cucut dengan menggunakan pelarut etanol, Sumaryanto et al. (1996) menggunakan etanol untuk mengekstrak protein ikan nila merah; Rieuwpassa (2005) mengekstrak protein ikan teri menggunakan pelarut etanol; Koesoemawardani dan Nurainy (2008) menggunakan pelarut etanol untuk mengekstrak protein ikan rucah; Tirtajaya et al. (2008) mengekstrak protein ikan patin (Pangasius pangasius) menggunakan etanol dan isopropil alkohol; Widiyawati (2011) mengekstrak protein ikan lele (Clarias gariepenus) menggunakan pelarut etanol ; Chalamaiah et al. (2011) menggunakan isopropil alkohol untuk mengekstrak protein ikan Cirrihinus mrilaga; Wiharja et al. (2013) menggunakan etanol untuk mengekstrak protein telur ikan tuna dan kakap merah; sedangkan Rao (2014) menggunakan isopropil alkohol untuk mengekstrak protein telur mas (Cyprinus carpio) dan Epinephelus tauvina dan Siahaan et al. (2015) menggunakan isopropil alkohol untuk mengekstrak protein ikan gabus (Channa striatus).

Keistemewaan konsentrat protein ikan selain nilai gizinya tinggi juga sifat fungsional proteinnya tidak hilang, sehingga dapat diolah lebih lanjut menjadi berbagai macam produk olahan daging. Dewita dan Syahrul (2010) menyatakan produk dengan penambahan KPI dikembangkan agar mampu meningkatan daya terima masyarakat terhadap produk konsentrat protein ikan.

FAO mengklasifikasikan konsentrat protein ikan menjadi tiga tipe, yaitu: pertama (tipe A) merupakan tepung ikan yang tidak berbau, tidak berasa ikan, dan tidak berwarna. Kandungan protein minimal 67,5\%, kadar lemak maksimal 0,75\%, dan kadar air maksimal $10 \%$. Kedua (tipe B) merupakan tepung ikan yang tidak memiliki spesifikasi bau, rasa dan warna tetapi bila ditambahkan kebahan makanan sebagian besar meninggalkan rasa ikan. Kandungan protein minimal 65\%, kadar lemak maksimal 3\% dan kadar air maksimal $10 \%$. Ketiga (tipe C) merupakan tepung ikan yang 
dibuat secara higienis, dengan kandungan protein ikan minimal 60\%, kadar lemak maksimal $10 \%$ dan kadar air maksimal $10 \%$ serta masih meninggalkan bau dan rasa ikan (Buckle, 1987).

Proses pembuatan konsentrat protein ikan yang ideal, selain ekonomis, juga harus memproduksi produk yang mempunyai sifat-sifat sebagaiberikut; pertama, nilai gizinya sama dengan daging ikan awal; kedua, kandungan airnya dapat dikembalikan ke kadar daging ikan mula-mula; ketiga, bersifat steril secara bakteriologik; keempat tidak berasa, tidak berbau, atau mempunyai rasa dan bau yang menyenangkan; kelima stabil dalam kondisi atmosfer dan keenam tidak mengandung residu yang toksik (Tranggono, 1991).

Menurut Ibrahim (2009), konsentrat protein ikan merupakan produk yang dihasilkan dengan cara menghilangkan lemak dan air sehingga menghasilkan konsentrat protein yang tinggi. Kebanyakan produk ini diaplikasikan ke dalam makanan yang berkarbohidrat tinggi. Pembuatan konsentrat protein ikan merupakan inovasi pengembangan bentuk protein yang mudah diaplikasikan kedalam produk pangan berprotein rendah.

\section{BAHAN DAN METODE}

Penelitian dilaksanakan pada bulan Februari hingga Agustus tahun 2012 di laboratorium kimia dan work shop pengolahan hasil Sekolah Tinggi Perikanan Jakarta. Penelitian ini didesain sebagai penelitian eksperimental yaitu penelitian yang dilakukan untuk mendapat informasi mengenai keragaan mutu KPI dengan perlakuan jenis pelarut dan ulangan ekstraksi yang berbeda. Metode pengumpulan data yang diterapkan adalah dengan melakukan percobaan skala laboratorium, menggunakan percobaan. Rancangan yang digunakan adalah Rancangan Acak Lengkap Pola Faktorial untuk pembuatan Konsentrat Protein Ikan (KPI). Rancangan Acak Lengkap Pola Faktorial ini menggunakan dua perlakuan yaitu pengg pelarunaan pelarut yang berbeda (etanol dan IPA) serta empat tahapan ekstraksi (1, 2, 3 dan 4 kali) dikeringkan menggunakan oven dengan suhu $40^{\circ} \mathrm{C}$ selama 8 jam dan ulangan dilakukan tiga kali. AE1: KPI perlakuan pelarut IPA 1 kali ekstraksi; AE2: KPI perlakuan pelarut IPA 2 kali ekstraksi; AE3: KPI perlakuan pelarut IPA 3 kali ekstraksi; AE4: KPI perlakuan pelarut IPA 4 kali ekstraksi;

BE1 : KPI perlakuan pelarut etanol 1 kali ekstraksi;

BE2 : KPI perlakuan pelarut etanol 2 kali ekstraksi;

BE3 : KPI perlakuan pelarut etanol 3 kali ekstraksi;

BE4 : KPI perlakuan pelarut etanol 4 kali ekstraksi.

Peubah yang dianalisis meliputi kadar protein, kadar lemak, kadar air dan nilai organoleptik. Pada
KPI terpilih dilakukan uji derajad putih dan propil asam amino.

\section{HASIL DAN PEMBAHASAN}

Hasil analisis proksimat menunjukkan bahwa kandungan protein ikan lele dumbo ukuran jumbo tergolong tinggi yaitu 17,09\%. Menurut Handayani dan Kartikawati (2015) komposisi gizi ikan lele kandungan air $75,10 \%$ protein $18,79 \%$, lemak $4,03 \%$, dan mineral 2,08\%. Menurut Venugoval (2008) bahwa ikan yang tergolong berlemak rendah, jika kadar lemaknya kurang dari $3 \%$, berlemak sedang memiliki kadar lemak 3-5\% dan berlemak tinggi mempunyai kadar lemak lebih dari 7 \%. Nurjanah (2011) menyatakan bahwa variasi komposisi gizi ikan dipengaruhi oleh faktor biologi mencakup jenis species, jenis kelamin, kematangan gonad, makanan, musim, kondisi perairan dan cara penanganan. Ikan lele termasuk ikan yang berlemak rendah dan kandungan proteinnya tinggi sehingga cocok diproses menjadi KPI.

a. Kadar Protein KPI lele dumbo ukuran jumbo

Protein berfungsi pembangun struktur utama dalam sel, enzim dalam membran, hormon dan alat pembawa. Dilihat dari sisi nutrisi, protein merupakan sumber energi dan asam amino, yang penting untuk pertumbuhan dan perbaikan sel (Winarno, 1998). Protein merupakan parameter terpenting dalam menentukan mutu konsentrat protein ikan. Ciri konsentrat protein ikan yang baik adalah kandungan protein yang tinggi, kadar lemak rendah. Konsentrat protein ikan dengan kwalitas yang tinggi memiliki kandungan protein minimal 67,5\%.

Hasil analisis ragam menunjukkan bahwa jenis pelarut dan pengulangan ekstraksi berpengaruh nyata $(\mathrm{p}<0,05)$ terhadap kadar protein KPI lele ukuran jumbo. Kadar protein KPI hasil ekstraksi dapat dilihat pada Gambar 1.

Hasil analisis varians menunjukkan bahwa jenis pelarut berpengaruh sangat nyata $(a=0,01)$ terhadap kadar protein KPI. Hasil kadar protein KPI lele dumbo ukuran jumbo yang diekstrak menggunakan pelarut IPA lebih tinggi dibanding dengan protein KPI lele dumbo ukuran jumbo yang diekstrak dengan menggunakan etanol. Kemampuan masing-masing pelarut untuk mengagresi protein serta mengekstraksi lemak dan air berbeda sehingga akan mempengaruhi kadar protein dan lemak KPI yang dihasilkan. Hal ini sesuai dengan pendapat McPhee dan Dubrow (1972), bahwa IPA merupakan pelarut yang baik dalam pembuatan KPI dibanding etanol. Hasil penelitian Rieuwpassa et al. (2013) penggunaan pelarut IPA menghasilkan kadar protein KPTI yang lebih tinggi 


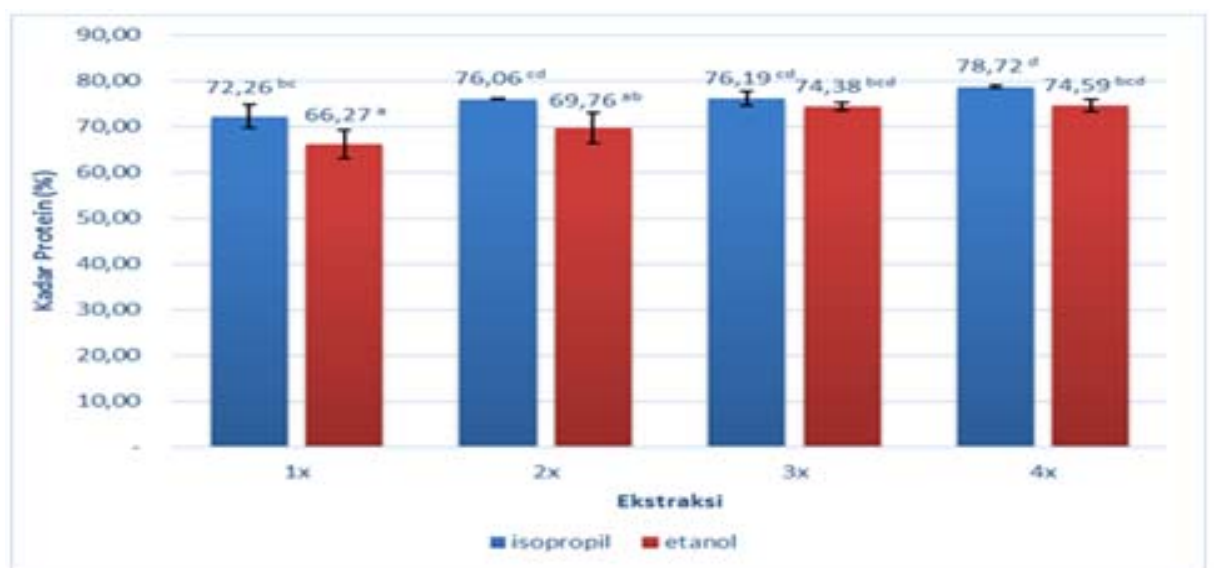

Gambar 1. Histrogram pengaruh jenis pelarut dan pengulangan ekstraksi terhadap kadar protein KPI leleukuran jumbo. Angka-angka dengan superskrip yang berbeda $(a, b, c)$ kadar protein pada konsentrat protein ikan menunjukkan perbedaan nyata.

dibanding dengan pelarut etanol. Etanol adalah pelarut organik yang bersifat polar sehingga etanol tidak hanya melarutkan lemak dan air tetapi juga sedikit protein terlarut. Menurut Winarno (2008) etanol memiliki gugus hidroksil yang bersifat polar dan gugus metil yang bersifat non polar sehingga sebagian kecil protein ikut terlarut.

Hasil analisis varians pengulangan ekstraksi berpengaruh sangat nyata ( $\mathbf{a}=0,01)$ terhadap kadar protein KPI lele dumbo ukuran jumbo. Hal ini disebabkan karena daya ekstraksi pelarut terhadap air dan lemak tinggi, maka protein akan semakin terkonsentrasi dan lemak akan semakin rendah. Pengulangan ekstraksi yang semakin banyak akan menyebabkan penurunan lemak dan air yang semakin tinggi sehingga protein semakin terkonsentrasi. Interaksi antara perlakuan banyaknya ekstraksi dan jenis pelarut tidak menunjukkan adanya hubungan. Kemampuan masing-masing pelarut untuk mengagregasi protein serta mengekstraksi lemak dan air berbeda sehingga akan mempengaruhi kadar protein dan lemak KPI yang dihasilkan.

Berdasarkan uji lanjut Tukey ekstraksi 1 berbeda nyata dengan ekstraksi 2, 3, dan 4. Diduga karena lama ekstraksi per kali ekstraksi hanya 20 menit kemungkinan karena waktunya singkat ekstraksinya belum sempurna sehingga hanya sedikit lemak dan air yang terekstraksi. Menurut Rieuwpassa et al. (2013) ekstraksi terbaik diperoleh pada perlakuan isopropil alkohol dengan frekuensi ekstraksi 3 jam. Ekstraksi 2 kali berbeda tidak nyata dengan ekstraksi 3 kali dan berbeda nyata dengan ekstraksi 4 kali. Ekstraksi 3 kali berbeda nyata dengan ekstraksi 4 kali. Pengulangan ekstraksi yang semakin banyak akan menyebabkan penurunan lemak dan air yang semakin tinggi sehingga protein semakin terkonsentrasi. Kadar protein tertinggi yang diperoleh dengan perlakuan IPA ekstraksi 4 kali pengulangan yaitu 78,71\% hal ini sesuai dengan pendapat Finch (1977) dalam Astawan (1990), penggunaan pelarut organik yang dapat digunakan untuk mengekstrak lemak dari suatu bahan adalah hidrokarbon (heksan dan sikloheksan), alkohol (etanol, isopropanol, isobutanol) dan etilen diklorida. Akan tetapi berdasarkan jumlah lemak yang dapat diekstrak, "National Academy of Sciense" merekomendasikan pemakaian isopropanol sebagai medium pengekstrak lemak.

Kadar protein KPI lele dumbo ukuran jumbo tertinggi yang diperoleh $(78,71 \%)$ lebih rendah dibanding hasil penelitian Widiyawati (2011) dengan nilai protein KPI ikan lele 81,60\% dengan menggunakan pelarut etanol 95\%, hal ini kemungkinan disebabkan karena jenis pelarut berbeda (IPA). Kadar protein yang berbeda-beda pada beberapa konsentrat protein dipengaruhi oleh beberapa faktor diantaranya jenis ikan, cara ekstraksi, jenis pelarut, lama ekstraksi dan cara pengeringan.

\section{b. Kadar Lemak KPI lele dumbo ukuran jumbo}

Ikan banyak mengandung asam lemak tidak jenuh, oleh karena itu sangat peka terhadap proses oksidasi. Pengaruh luar seperti suhu, radiasi, logam katalis dapat mempercepat laju oksidasi asam lemak tersebut, yang akibat lanjutannya, terjadilah penurunan mutu zat gizi yang terkandung dalam bahan tersebut (Cahayati, 1998). Salah satu faktor penentu mutu KPI adalah kadar lemak, semakin rendah kadar lemak KPI semakin tinggi mutu KPI. KPI tipe A memiliki kadar lemak kurang dari $0,75 \%$, KPI tipe B mengandung kadar lemak kurang dari 3\% dan KPI tipe $C$ mengandung kadar lemak kurang dari 10\% (FAO 1976). Hasil uji kadar lemak KPI lele dumbo ukuran jumbo dapat dilihat pada Gambar 2. 


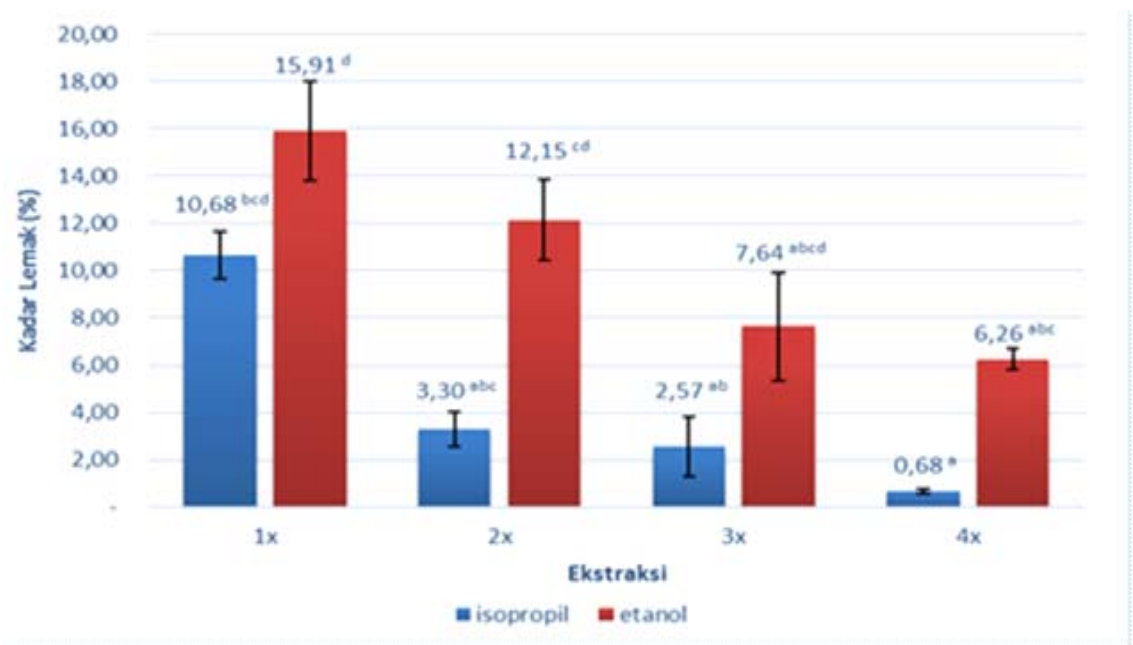

Gambar 2. Histogram pengaruh jenis pelarut dan pengulangan esktraksi terhadap kadar lemak KPI lele dumbo ukuran jumbo. Angka-angka dengan superskrip yang berbeda (a,b,c,d) lemak pada konsentrat protein ikan menunjukkan perbedaan nyata.

Hasil analisis varian menunjukkan bahwa penggunaan jenis pelarut berpengaruh sangat nyata( á $=0,01$ ) terhadap penurunan kadar lemak KPI lele afkir. Kadar lemak rata-rata KPI yang terendah dibuat dengan menggunakan pelarut IPA $(0,69 \%)$ sedangkan kadar lemak rata-rata KPI terendah yang didibuat dengan menggukan pelarut etanol ( $6,17 \%)$. Penggunaan pelarut IPA untuk ekstraksi lemak pada pembuatan KPI ikan lele ukuran jumbo lebih baik dibandingkan etanol. Hasil penelitian Rieuwpassa et al. (2013) jenis pelarut berpengaruh terhadap kadar lemak, KPTI pelarut IPA $(2,78 \%)$, pelarut etanol $(6,09 \%)$. Jika daya ekstraksi pelarut terhadap air dan lemak tinggi, maka protein akan semakin terkonsentrasi dan lemak akan semakin rendah. Menurut Tirtajaya et al. (2008), kemampuan masing-masing pelarut untuk mengagregasi protein serta mengekstraksi lemak dan air berbeda sehingga akan mempengaruhi kadar protein dan lemak konsentrat protein ikan yang dihasilkan. Pelarut alkohol merupakan pelarut organik bersifat polar yang memiliki kemampuan untuk memisahkan fraksi gula larut air dan lemak tanpa melarutkan proteinnya (Amoo et al., 2006).

Banyaknya ulangan ekstraksi berpengaruh sangat nyata $(a ́=0,01)$ terhadap kadar lemak KPI. Pengulangan ekstraksi yang semakin banyak akan menyebabkan penurunan lemak dan air yang semakin tinggi sehingga kadar lemak akan semakin rendah.

Berdasarkan uji Tukey kadar lemak rata-rata KPI hasil dari ekstraksi $4(0,69 \%)$ berbeda dengan ekstraksi $3(2,57 \%)$, ekstraksi $2(3,30 \%)$ dan ekstraksi $1(10,68 \%)$ . Ekstraksi 2 tidak berbeda nyata dengan ekstraksi 3 , berbeda sangat nyata dengan ekstraksi ke 4 . Kadar lemak rata-rata hasil ekstraksi 3 berbeda sangat nyata dengan ekstraksi 4. Hal ini dikarenakan proses ekstraksi berulang mampu mendegrasi lemak, semakin lama ekstraksi akan menghasilkan kadar lemak yang rendah.

Hasil uji kadar lemak terendah diperoleh pada perlakuan pelarut IPA dengan 4 kali ulangan ekstraksi yaitu 0,69\% lebih rendah dari Djafar et al. (2010) dengan kadar lemak KPI ikan nila merah $(1,23 \%)$. Menurut Rawdkuen et al. (2009) bahwa proses ekstraksi selain mengekstraksi lemak juga menghilangkan material-material lain seperti darah, pigmen dan bahan-bahan penyusun bau.

Kadar air pada produk perikanan akan berpengaruh pada daya awet produk perikanan, air adalah media yang sangat baik untuk pertumbuhan bakteri. Produk yang mengandung kadar air yang rendah semakin panjang daya awetnya. Hasil uji kadar air KPI dapat dilihat pada Gambar 3.

Hasil analisis varian menunjukkan bahwa pengulangan ekstraksi tidak memberikan berpengaruh nyata $(p>0,05)$ terhadap kadar air rata-rata KPI lele dumbo ukuran jumbo. Ekstraksi 1 dengan pelarut IPA $(9,76 \%)$ tidak berbeda nyata dengan ekstraksi $2(9,70 \%)$, ekstraksi $3(9,72 \%)$ dan $4(9,91 \%)$. Hal ini diduga karena ekstraksi dilakukan selama 20 menit per tiap kali ekstraksi sehingga kemampuan ekstraksinya rendah. Menurut Ibrahim (2009), konsentrat protein ikan merupakan produk yang dihasilkan dengan cara menghilangkan lemak dan air. Kemampuan masingmasing pelarut untuk mengagregasi protein serta mengekstraksi lemak dan air yang dihasilkan berbeda.

Berdasarkan uji lanjut Tukey ekstraksi 2 tidak berbeda nyata dengan ekstraksi 3 dan berbeda nyata dengan ekstraksi 4. Ekstraksi ke 3 tidak berbeda nyata dengan ekstraksi 4. Hal ini disebabkan karena selama 


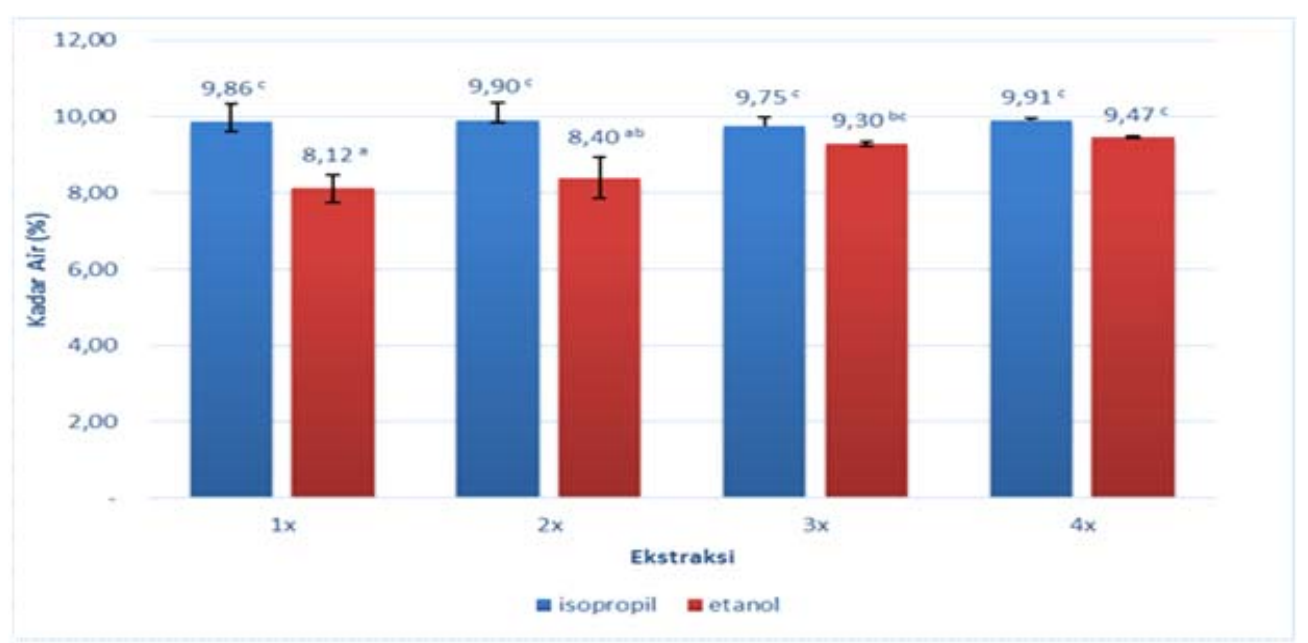

Gambar 3. Histrogram pengaruh jenis pelarut dan pengulangan ekstraksi terhadap kadar air rata-rata KPI lele dumbo ukuran jumbo. Angka-angka dengan huruf $(a, b, c)$ superskrip yang berbeda menunjukkan perbedaan.

ekstraksi akan melarutkan lemak dan air sehingga semakin banyak (ekstraksi ke 4) semakin kecil kadar airnya.

\section{c. Nilai Organoleptik Konsentrat Protein Ikan}

Salah satu mutu KPI adalah nilai organoleptik (aroma). Nilai organoleptik aroma KPI lele dumbo ukuran jumbo ditentukan dengan menggunakan uji skoring. Skor yang diberikan sebagai berikut; $1=$ aroma ikan sangat kuat, $2=$ aroma ikan kuat, $3=$ aroma ikan lemah $4=$ aroma ikan sangat lemah, $5=$ tidak beraroma ikan. KPI yang bermutu baik memiliki nilai aroma ikan yang lemah saat disedu dengan air panas. Hasil uji organoleptik aroma KPI dapat dilihat pada Gambar 4.
Nilai Kruskal Wallis menunjukkan adanya pengaruh sangat nyata (á=0.01) antara banyaknya ekstraksi dan jenis pelarut terhadap mutu organoleptik (aroma). Hasil uji nilai tertinggi aroma $(4,37)$ diperoleh pada perlakuan ekstraksi dengan menggunakan pelarut IPA pada ulangan ekstraksi ke 4. Hal ini sesuai dengan hasil penelitian (Rieuwpassa et al.2013) nilai tertinggi bau diperoleh pada perlakuan ekstraksi menggunakan pelarut IPA lama ekstraksi 3 jam. Proses ekstraksi bertujuan menghilangkan bau amis. Tujuan proses ekstraksi menggunakan alkohol, selain melarutkan kadar lemak juga bertujuan untuk mengurangi atau menghilangkan aroma amis ikan pada KPI. Semakin banyak lemak yang diekstrak semakin lemah aroma amis ikan, semakin tinggi nilai organoleptik aroma

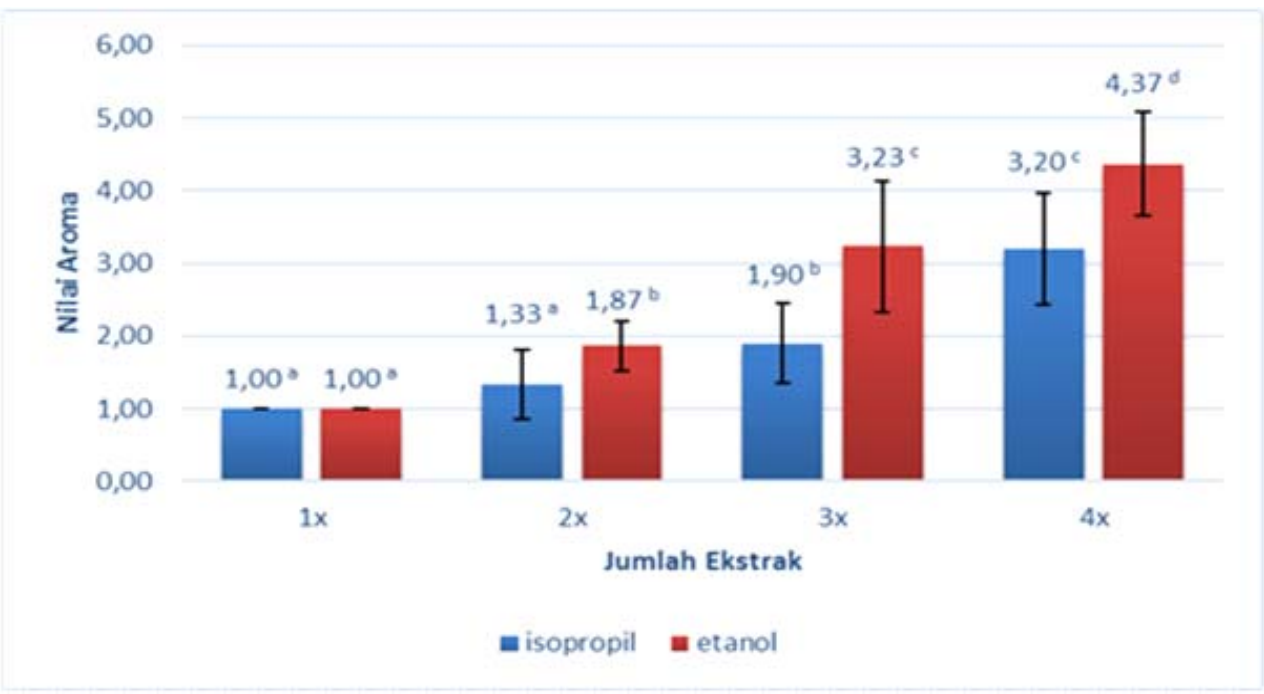

Gambar 4. Histrogram pengaruh jenis pelarut dan pengulangan ekstraksi terhadap nilai aroma KPI lele dumbo ukuran jumbo. Angka-angka dengan huruf (a,b,c,d) superskrip yang berbeda menunjukkan perbedaan. 
KPI. Proses ekstraksi tidak hanya mampu melarutkan lemak, akan tetapi juga menghilangkan material-material lain seperti darah, pigmen dan bahan penyusun aroma (Rawdkuen et al. 2009). Hal ini diduga karena selama ekstraksi lemak dan material lain ikut terekstrasi sehingga bau amis ikan semakin banyak terekstraksi, sehingga bau amis ikan semakin kecil.

\section{Pemilihan Metoda Pembuatan KPI Terbaik}

Parameter yang paling dipertimbangkan dalam pemilihan metoda pembuatan KPI lele dumbo ukuran jumbo terbaik adalah kadar protein, kadar lemak, kadar air, mutu organoleptik (aroma). Pemilihan metoda pembuatan konsentrat protein ikan terbaik ditentukan berdasarkan syarat mutu KPI menurut FAO (1976). Hasil penenilitian menunjukkan bahwa perlakuan jenis pelarut dan pengulangan ekstraksi berpengaruh sangat nyata (á $=0,01)$ terhadap kadar protein, kadar lemak dan nilai aroma KPI lele dumbo ukuran jumbo, sedangkan nilai kadar air tidak memberikan pengaruh nyata $(p>0,05)$. Metoda terbaik dalam pembuatan KPI lele dumbo ukuran jumbo adalah dengan ekstraksi yang menggunakan pelarut isopropil alkohol konsentrasi $90 \%$, dengan 4 kali pengulangan, lama ekstraksi 20 menit memiliki kadar protein yang paling tinggi 78,71\%, kadar lemak terendah 0,69\% dan nilai organoleptik tertinggi $(4,37)$.

a. Nilai gizi KPI lele dumbo ukuran jumbo

Nilai gizi KPI lele dumbo ukuran jumbo dilakukan uji protein, lemak, air dan abu. Hasil gizi KPI lele dumbo ukuran jumbo dapat dilihat pada Tabel 1 .
Menurut Kusnandar (2010) protein merupakan senyawa organik komplek yang mengandung asam amino yang terikat satu sama lain melalui ikatan peptida. Protein merupakan molekul esensial dalam menyusun struktur maupun proses fungsional tubuh makluk hidup. Hasil penelitian menunjukkan bahwa kadar protein KPI lele dumbo ukuran jumbo 78,71\%, lebih rendah dibanding hasil penelitian Widiyawati (2011) yang menghasilkan kadar protein KPI lele afkir $81,60 \%$. Lebih rendah dibanding dengan hasil penelitian Santoso et al. (2008) yang menghasilkan kadar protein KPI nila hitam $81,62 \%$. Hasil penelitian KPI lele dumbo ukuran jumbo tergolong KPI tipe A sesuai persyaratan FAO (1976).

Kusnandar (2010) lemak adalah senyawa ester non polar yang tidak larut air. Setiap jenis pangan memiliki kadar lemak yang berbeda akan berpengaruh terhadap daya awet pangan. Hasil penelitian menunjukkan kadar lemak KPI lele dumbo ukuran jumbo $0,69 \%$, lebih rendah dari hasil penelitian Widiyawati (2011) KPI lele dumbo ukuran jumbo dengan kadar lemak 1,24\%, dan lebih rendah dari hasil penelitian Santoso et al. (2008) kadar lemak KPI nila hitam 1,89\%. Menurut syarat FAO (1976), KPI lele dumbo ukuran jumbo dengan kadar lemak terendah 0,69\% tergolong pada KPI tipe A.

Kadar air dalam pangan sangat penting pengaruhnya terhadap daya simpan pangan. Kadar air yang rendah akan memperpanjang daya simpannya. Hasil penelitian menunjukkan bahwa kadar air KPI lele dumbo ukuran jumbo $9,91 \%$, lebih tinggi dibanding dengan hasil penelitian Widiyawati (2011) yang menghasilkan kadar

Tabel 1. Komposisi Nilai Gizi KPI Lele Dumbo Ukuran Jumbo

\begin{tabular}{lcc}
\hline \multicolumn{1}{c}{ Parameter } & Nilai & Pembanding \\
\hline Protein \% & $78,71 \pm 0,43$ & $81,60 \pm 0,44^{\mathrm{a}}$ \\
Lemak \% & $0,69 \pm 0,01$ & $1,24 \pm 0,15^{\mathrm{a}}$ \\
Air \% & $9,91 \pm 0,06$ & $8,65 \pm 0,06^{\mathrm{a}}$ \\
Abu\% & $1,5 \pm 0,19$ & $1,46 \pm 0,18^{\mathrm{b}}$ \\
Karbohidrat by difference \% & $9,63 \pm 0,2$ & $13,93 \pm 0,15^{\mathrm{b}}$ \\
\hline
\end{tabular}

a)Widiyawati (2011) ; b) Santoso et al (2008)

air KPI lele dumbo afkir 8,65\% dan lebih tinggi dibanding hasil penelitian Ibrahim (2009) yang menghasilkan kadar air KPI ikan nila 4,18\%. Menurut FAO (1976) kadar air maksimum KPI sebesar $10 \%$.

Kadar abu pada bahan pangan menunjukkan adanya kandungan mineral-mineral dalam pangan. Kusnandar (2010) yang dimaksud mineral adalah kompenen organik misal; sulfur (S), fosfor(P), kalsium (Ca). Hasil penelitian menunjukkan kadar abu KPI lele afkir 1,5\%, lebih tinggi dibanding hasil penelitian Santoso et al. (2008) kadar abu KPI nila hitam 1,46\%.
Kandungan karbohidrat dalam daging ikan berupa polisakarida, yaitu glikogen yang terdapat di dalam sarkoplasma diantara miofibril-miofibril. Kadar karbohidrat KPI lebih tinggi dibanding dengan kadar karbohidrat daging ikan segar. Kadar kabohidrat (by difference) hasil penelitian KPI lele dumbo ukuran jumbo 9,63\%, hasil ini lebih rendah dibanding dengan hasil penelitian Santoso et al. (2008) kadar karbohidrat (by difference) nila hitam 13,93\%.

Derajat putih adalah analisis yang menentukan keputihan suatu bahan yang sangat erat dengan daya 
terima konsumen. Hasil penelitian nilai derajat putih KPI lele dumbo ukuran jumbo pada perlakuan pelarut IPA dengan 4 kali pengulangan ekstraksi dengan nilai 85, hasil ini lebih tinggi dibanding dengan hasil penelitian Santoso et al. (2008) derajat putih KPI nila hitam 75,81. Peningkatan warna putih disebabkan oleh berkurangnya kadar lemak selama ekstraksi.

Hasil penelitian menunjukkan asam amio KPI lele dumbo ukuran jumbo 69,96\% dari 71,30\% protein. Lysin merupakan asam amino esensial dengan jumlah tertinggi $(7,71 \%)$ dibanding asam amino esensial lainnya. Ikan mengandung asam amino lysine dalam jumlah yang tinggi dibanding dengan asam amino metionin yang rendah (Hussain et al., 2007).

Konsentrat protein ikan lele dumbo ukuran jumbo mengandung asam amino lysine $7,71 \%$ dari berat protein. Hasil ini telah memenuhi persyaratan FAO kandungan lysine minimum 6,5\% dari berat protein. Asam amino pembatas pada komposisi asam amino KPI lele dumbo ukuran jumbo adalah tyrosine. Menurut Muchtadi (1993) data asam amino pembatas berguna untuk mengetahui asam amino esensial yang harus disuplementasi untuk meningkatkan nilai gizi protein. Konsentrat protein ikan lele dumbo ukuran jumbo memiliki 8 asam amino esensial, 5 asam amino non esensial dan 2 asam amino semi esensial hasil ini telah sesuai dengan hasil penelitian Rieuwpassa et al. (2013) KPIT cakalang menghasilkan 8 asam amino esensial, 5 asam amino non esensial dan 2 asam amino semi esensial.

\section{KESIMPULAN}

Berdasarkan hasil dari temuan dan pembahasan dapat diambil kesimpulan, Metode terbaik pembuatan KPI berbahan baku ikan lele dumbo ukuran jumbo menggunakan pelarut isopropil alkohol 90\%, pengulangan ekstraksi 4 kali menghasilkan kadar protein $78,71 \%$, kadar lemak $0,69 \%$, derajat putih 84 , nilai organoleptik 4,29 bau ikan sangat lemah dan memiliki 8 asam amino esensial, 5 asam amino non esensial dan 2 asam amino semi esensial. KPI ikan lele dumbo ukuran jumbo berupa produk dalam bentuk tepung berwarna putih yang mudah diplikasikan sebagai bahan fortifikasi keproduk.

\section{UCAPAN TERIMA KASIH}

Penulis mengucapkan terima kasih kepada Ketua Sekolah Tinggi Perikanan.

\section{DAFTAR PUSTAKA}

Alamendah. (2009). Klasifikasi dan jenis ikan lele http/ alamendah word press. Com/2009/09/21/Klasifikasi dan jenis ikan lele diakses tanggal 28 Mei 2011.
Amoo, I.A, Adebayo, O.T., \& Oyeleye, AO.(2006). Chamical evaluation of winged beans (Psophocarous tetragonolabus), pitanga cherries (Eugenia uniflora) and orchid fruit (Orchid fruit myristica). African.J Food Agric.Nutr.Dev.6(2):1-12.

Ariani, M. (2010). Analisis konsumsi pangan tingkat masyarakat mendukung pencapaian diversifikasi pangan. Jurnal Gizi Indonesia 33 (1): 20-28.

Astawan, M. (1990). Pengaruh pengolahan terhadap nilai gizi dan sifat fungsional konsentrat protein ikan. Tesis. Progam Pascasarjana. Institut Pertanian Bogor.

Buckle,K.A.,Edwards,R.A., Fleet,G.H., \& Wooton, M. (1987). Ilmu Pangan Diterjemahkan oleh Purnomo, H., Adiono. Jakarta: UI Press.

Cahayati,I. (1998). Hidrolisis minyak ikan lemuru (Sardinila longiceps) dengan lipase spesifik 1-3 dari Rhizopus oryzae dan Aspergilus niger Untuk mengkonsentrasikan EPA dan DHA dalam gliserida, Tesis. Jurusan Teknologi Pangan Fakultas Pertanian UGM Yogyakarta.

Chalamaniah, M.K., Balaswamy,G.N., Galla, P.G., Prabhakara Galla., \& Jyothirmayi, T. (2011). Chemical composition and functional properties of mrigal (Cirrhinus mrigala) egg protein concentrates and their application in pasta. J.Food Sceences Technology. DOI 10.1007/s13197-00110357-5.

Dewita., \& Syahrul. (2011). Laporan Hibah Kompetensi Kajian diversifikasi ikan patin (Pangasius sp.) dalam bentuk konsentrat protein ikan dan aplikasinya pada produk jajanan untuk menanggulangi gizi buruk pada anak balita di Kabupaten Kampar Riau, Lembaga Penelitian Universitas Riau Pekanbaru.

Dewita., \& Syahrul. (2014). Fortifikasi konsentrat protein ikan patin siam pada produk snack amplang dan mi sagu instan sebagai produk unggulan daerah Riau JPHPI 17(2): 156-164

Djafar, J.M., (2010). Aplikasi penggunaan konsentrat protein ikan dalam pembuatan produk pangan berprotein tinggi. Pusat Teknologi Agroindustri Deputi Bidang Teknologi Agroidustri Dan Bioteknologi Badan Pengkajian dan Penerapan Teknologi.

FAO. (1976). Guidelines on Formulated Suplementary Foods for Older Infants and Young Children. Rome: Food and Agriculture Organization.

Finch, R. (1977). Whatever Happened to Fish Protein Concentrat Food Technologi.

Handayani D.W., \& Kartikawati D. (2015) Stiklele alternatif diversifikasi olahan lele (Clarias sp.) tanpa limbah berkalsium tinggi. Jurnal Ilmiah UNTAG Semarang. 4(1) : 109-117 
Haslina, Muis, S.F., \& Suyatno. (2006). Nilai gizi, daya cerna protein dan daya terima patilo sebagai makanan jajanan yang diperkaya dengan hidrolisat protein ikan mujair. Jurnal Gizi Indonesia 1(2): 3440.

Hussain, N., Akhtar, N., \& Hussain, S.(2007). Evaluation of weaning food khitchri incorporated with different levels of fish protein concentrate. Animal Plant Sci.7(1-2):12-17.

Ibrahim, M.S. (2009). Evaluation of production and quality of salt biscuits supplemented with fish protein concentrate. World J Dairy Food Sciences, $4(1): 28-31$.

Koesoemawardani, D., \& Nurainy, F. (2008). Karakterisasi konsentrat protein ikan rucah. Seminar Nasional Sains dan Teknologi II 2008 Jurusan Teknologi Hasil Pertanian Univesitas Lampung 1718 November 2008 VIII -32.

Khairuman., \& Aman, K. (2002). Bududaya Ikan Di Sawah Jakarta Agromedia Pustaka.

Kusnandar, F. (2010). Kimia Pangan Komponen Makro Seri 1 Jakarta (ID): PT. Dian Rakyat.

Muchtadi, T.R. (2008). Teknologi Proses Pengolahan Bahan Pangan.Bogor: Fakultas Teknologi Pertanian, Institut Pertanian Bogor.

Nurilmala, M., Nurjanah., \& Utama, R.H.(2009). Kemunduran Mutu Ikan Lele Dumbo. Jurnal Pengolahan Hasil Perikanan Indonesia 12 (1) 1-16 Tahun 2009 Institut Pertanian Bogor.

Nurjanah, Abdullah,A.,Tarman, (2011). Pengetahuan dan Karakteristik Bahan Baku Hasil Perairan Bogor (ID): IPB.Press.

Rao,G.N., Balaswamy, K., Satyanarayana, A., \& Galla, P.P. (2012). Phisico chemical amino acit compotion, fungtional andin concentrat antioxidant propertis of roe protein concentrates obtained from Channa striatus and Lates Calcarifer Food Chem 132 (3): 1171-1176.

Rawdkuen,S., Samart, S.U., Khamsorn, S., Chaijan, M., \& Benjakul, S. (2009). Biochemical and gelling propertties of Tilapia Surimi and protein recovered using an acid-alkaline process. Food Chemistry, 112: 112-119.

Rieuwpassa, F. (2005). Biskuit konsentrat protein Ikan dan probiotik sebagai makanan tambahan untuk meningkatkan antibodi IgA dan status gizi anak balita . Desertasi. Sekolah Pascasarjana Institut Pertanian Bogor.
Rieuwpassa, F., Santoso, J., \& Trilaksani, W. (2013). Karakeristik sifat fungsional konsentrat protein telur ikan cakalang (Katsuwonus pelamis). Jurnal Ilmu dan Teknologi Kelautan Tropis 5 (2): 299309, FPIK -IPB.

Rohimah, I., Etti, S., Ernawati, N.( 2014). Analisis energi dan protein serta daya terima biskuit tepung labu kuning dan ikan lele. Jurnal USU, Ac.id/ index. php/gkre/article/viewfile/5160/2781.

Rosa, R., Bandara, N.M., \& Nunes, M.I.(2007). Nutritional quality of African cat fish Clarias gariepinus (Burchell 1822):A positive criterion for the future developmant of Siluroidei, Journal Food Science and Technology 42:342-351.

Santoso, J., Hendra, E., \& Siregar, M.T., (2008). Pengaruh lama pengulangan Ekstraksi Terhadap karakteristik fisika kimia konsentrat protein ikan nila hitam (Oreochromis niloticus). Jurnal Ilmu dan Tenologi Pangan, 6(2): 67-84

Siahaan, WS., Sari,I.N., \& Loekman,S. (2015) Pengaruh penambahan konsentrat protein ikan gabus (Channa striatus) terhadap mutu kwetiau.

Tirtajaya, I., Santoso,J., \& Dewi,K. (2008). Pemanfaatan konsentrat protein ikan patin (Pangasius pangasius) pada pembuatan cookies coklat. J Ilmu teknologi Pangan ,6(2): 87-103

Tranggono, (1991). Bahan Tambahan Pangan (Food Additives). PAU Pangan Gizi. UGM Press, Yogyakarta. Venugoval, V. (2008). Seafood Processing; adding value through quick freezing retortable packaging and cook-chilling. New York: Taylor dan Prancis.

Windsor, M.L. (2001). Fish Protein Concentrate. Minestri of Technology Torry Researh Station. Torry Advisory Note No 39. FAO in Partnership with Support Unit for International Fisheries and Adequate Researh. Sifar. 2001 http:/www/fao/ wairdocs/tan/x5917E/x5917e01htm (21/09/2009).

Winarno,F.G.(2008) Kimia Pangan dan Gizi Bogor (ID)M.Brio Press.

Winarno, F.G.(1997). Kimia Pangan dan Gizi. Jakarta: PT Gramedia. 